\title{
WE, THE PEOPLE AND THE WORLD: AMERICAN LIBERALISM'S TROUBLED RELATIONSHIP WITH INTERNATIONAL LAW ${ }^{2}$
}

\begin{abstract}
The emergence of law in society and the role that it occupies are fundamental to any account of liberal theory. As difficult as it is to secure agreement as to the ontological nature and epistemic requirements of law on a liberal view, the challenges that confront the liberal idea of law increase exponentially when considered as an international phenomenon. It is when justice is conceived of beyond the territorial borders of the modern sovereign state that problems emerge with the greatest acuity for liberals, as there is no international tribunal to genuinely and definitively adjudicate claims. Contrary to the ideals of many liberals, power still essentially reigns supreme among nations, a reality that sits uncomfortably with legalistic liberalism itself.
\end{abstract}

Keywords: Liberalism, international law, sovereignty, humanitarian intervention, Nuremberg

One is hard pressed to find an account of liberalism - be it by its proponents or by its critics-that does not feature the rule of law as one of its main tenets, if not as its central normative feature. And whether this rule of law emerges as a moral duty to pull unfortunate members of a territorially-defined group out of a state of nature and into a civil society on the basis of autonomy and freedom, as in the Kantian account defended by Anna Stilz; as an administrative process yet to be tamed by thoughtful democratic deliberative reasoning, as with Henry S. Richardson; as the fetishized locus of a political-theological project, as presented in the manner of a foundational myth by Paul Kahn; or alternately, as a symptom of political sovereignty's shift from boundedness to aggrandizement through will, as is Jean Bethke Elstain's contention; to finally, a necessary evil, to be viewed with some democratic wariness and a good dose of pluralist scepticism, as with Michael Walzer, the law is, however variable, nonetheless always important. In fact, it is critical (Shklar, 1964; Stilz, 2009; Richardson, 2002; Elshtain, 2008; Kahn, 2005; Walzer, 2007).

1 tiphaine@pdx.edu

2 This article is based on the research completed for the sake of the dissertation titled "On the Poverty, Rise and Demise of International Criminal Law" defended at Portland State University on March 16th, 2016. 
As difficult as it is to secure agreement as to the ontological nature and epistemic requirements of law on a liberal view, the challenges that confront the liberal idea of law increase exponentially when considered as an international phenomenon. It is not a coincidence that (Shklar, 1964) chose to write about the Nuremberg and Tokyo trials. It is when justice is conceived of beyond the territorial borders of the modern sovereign state that problems emerge with the greatest acuity for liberals. This is because-as Anna Stilz would know, though it is not something that she clearly lets on-Kant's assessment, in Perpetual Peace, of international relations existing as a state of nature has yet to change, all moral claims of rights to humanitarian intervention (Walzer, 2007), to the contrary notwithstanding (Kant, 1970). Kant is still not far from wrong today when he wrote that states have "no external tribunal to put their claims to trial" (Kant, 1970, p. 104), as indeed courts, which by nature must possess the capacity to enforce their own decisions, do not currently exist-with such an enforcement power-between states at the international level. ${ }^{3}$ Judicial bodies have, however, been created by the United Nations Security Council as well as by the Rome Treaty, and these courts-or "law-like political institutions," as Judith (Shklar, 1964, p. 156) would put it-have jurisdiction over individuals. The difficulty is that they have (absolute) jurisdiction only over individuals of those nations who are not permanent members of the Security Council, and who cannot themselves create ad hoc bodies, or who do not-more importantly-have the power to refuse to submit to the jurisdiction of a tribunal such as the International Criminal Court by, for instance, deciding to exercise their power of veto to prevent the referral of an investigation of their own nationals.

Several issues are thus apparent, and require some explanation and justification by liberals. International justice-or perhaps more accurately, international law-when set out in such a stark manner, may appear illiberal in many ways. First, inconsistent application of the law can appear to do violence to principles of equality and fairness. The lack of universality in the application of the repressive mechanisms of international criminal law suggests that the process may be arbitrary, depending, for its implementation, on inconsistent assessments, and more troublingly, is sensitive to power to an unacceptable degree, and thus violates deeply held liberal commitments to the principle of equality. Secondly, the extent to which politics (in this instance, international politics) play a role in the determination of situations that require adjudication (or intervention) seem removed from the type of rationally-based procedural mechanisms liberals are committed to when issues are determined in a legal or judicial manner.

Finally, power wields a far greater influence in the determination of what (or who) will or will not be scrutinized by international "law-like political institutions" than what liberals are generally comfortable with. This last point coexists with liberalism's occasionally uneasy view of sovereignty, as this idea is what, at least for some powers internationally, permits and justifies immunity from prosecution; it is also the same concept that is (often

${ }^{3}$ Under Article 36 of the Statute of the ICJ, the court does not have jurisdiction over a dispute without the consent of the state parties involved in the dispute. See "Case of the Monetary Gold Removed from Rome in 1943 (Preliminary Question), Judgment of June 15th 1954": I.C.J. Reports 1954, p. 19. When the ICJ has been aggressive in construing consent, states, including the United States, have simply refused to participate further in the merits stage of the case (See Charney, 1987; and see also Kahn, 2000a, p.35). 
by the same states who invoke it for the protection of their own interests) viewed as a platitudinous orthodoxy of a bygone era-or at least as something that in extreme cases, plays a counterproductive, if not frankly dangerous role in the international post-Cold War environment.

A corollary to these questions has to do with the kinds of wrongs that justify international legal action, and specifically whether there exists any (liberal) basis to state that individuals can claim a right to be protected against such wrongs, or, of greater relevance here, of a right (or perhaps duty) for states or other arrangements to intervene on behalf of such individuals when they are citizens of foreign states, on foreign soil, and thus subject to the law of another jurisdiction (Walzer, 2007, p. 255). Then, brutally put, are we prepared to kill to fulfil this purpose, and to sacrifice our own lives (Walzer, 2007, p. 256)?

Liberals will also take an interest in the manner in which international rights, duties, procedures and institutions come into existence; liberal commitments afford some importance to the nature of agreements that generate obligations, create law (whether it is genuinely enforceable or not), and in extreme cases, the ability to deprive individuals of liberty-such as in the context of an ad hoc or permanent criminal or war crimes prosecution-or to engage in war, which frequently extinguishes the lives of individuals, whether they be compatriots or people living in other states.

This essay examines these broad problems in historical context, and in light of the way certain contemporary liberals (and some of their critics) have addressed them. The main focus will be on questions of international law and in particular how this type of normative undertaking poses specific challenges for liberalism.

\section{Sovereignty}

It is perhaps tempting to make sovereignty out as the villain in this state of affairs, that which prevents claims of right from fully and fairly being adjudicated equally, against all, or even as the very cause of intemperate war and massive crimes committed by states. Before examining what sovereignty is responsible for, however, it is worth attempting to explore what it is (and in relation to what). This is of course a very difficult question, and efforts to define sovereignty may vary in clarity and quality across theorists and depend on their own ontological and political commitments. Paul Kahn describes what he presents as a distinctly American view (Kahn, 2005), of a popular sovereignty from which law derives legitimacy, and not the other way around, as is the case for others, where law precedes and limits sovereignty (Kahn, 2005, p. 58). This is "we, the people," and for Kahn, this refers not to mere majority rule; instead, popular sovereignty is a transhistorical project of a people creating and maintaining itself (Kahn, 2005, p. 13). This is obviously not the type of claim that a state could, on a legal view, invoke to object to foreign attack or intrusion. Claims of what we could call cultural sovereignty bear an uncomfortably close resemblance to claims of exceptionalism (Kahn, 2010), and Kahn has not shied from the implication that exceptionalism of the American kind is perceived abroad - and with particular relevance for the interest of this essay, regarding the United States' unwillingness to be subject to the International Criminal Court, specifically (Kahn, 2003) - as an expression of naked interest by a sole super-power. The idea of American exceptionalism, however, predates its superpower status by two hundred years, and thus 
a justification for the exceptionalist view must be found elsewhere. Clearly, for Kahn, it is not a crude matter of power. Nor is exceptionalism grounded in considerations of justice, as the view that commands international law apply to all other states and not to the U.S. was-quite obviously—not determined behind a veil of ignorance (Kahn, 2010). Instead, exceptionalism is more plausibly justified by the fact that America's popular sovereign acts and speaks exclusively through the law (Kahn, 2005, pp. 20-21). "At that point," writes Kahn, "the exception becomes the exceptional, as in American exceptionalism" (Kahn, 2010). The reference to "the exception" here is made explicitly (and somewhat disconcertingly) to Carl Schmitt, a theorist with whom Kahn has engaged in greater depth in his recent (Kahn, 2011). Though Kahn has made plain that he wishes to bring "liberalism in contact with Schmitt," and not adopt his illiberal views-in particular those that base sovereignty on a pre-political conception of a "people's substantive homogeneity" (Kahn, 2011, p. 20), Kahn nonetheless adopts a Schmittian theoretical structure to discuss what he maintains is a view of American political faith in popular sovereignty, which in the discrete case of American society runs precisely contrary to a homogenous view, demanding instead that popular sovereignty accommodate a diversity of immigrant groups and faiths.

This view of exceptionalism, while it accounts for a secular devotion to U.S. sovereignty, as a reflection of American identity and a justification for sacrifice, does not begin to engage with, much less justify an American (or liberal) position towards the sovereignty of other states. Is the mere fact of exceptionalism sufficient to justify that a state would hold others to norms while simultaneously shielding itself from the institutionalized enforcement of those very same rules?

\section{Humanitarian intervention}

Here, Michael Walzer can offer an account, though it may perhaps, when employed in this way, seem to focus too strongly on power. On the issue of humanitarian intervention, Walzer has argued that in the face of the commission of atrocities, those who can, should, intervene-and by intervention, what is meant here is military action. To rebut the implication that this moral claim anoints the powerful and the enlightened (who may well be the "we" to whom he refers affectionately, and which is described by Judith Shklar as “we', his favourite characters" (Shklar, 1998, p. 379)) to act as Wild West vigilantes, Walzer instead relies on the examples of three let us call them "Third World" humanitarian interventions to demonstrate that proximity is sometimes the kind of "can" that leads to a "should" (Walzer, 2007, p. 255), which is an ability that generates an obligation to act. The problem with the cases that he cites-and this exemplifies a wider problem with doing justice through the infliction of military sentences without the benefit of a judicial institution to weigh evidence and sort out facts from rhetoric, however well intentionedis that all three "humanitarian interventions" could be reasonably justified as responses to aggression.

Tanzania repelled Ugandan troops that were unlawfully on (and claiming) its territory; Vietnam responded to repeated aggressions on its territory by an increasingly bellicose Cambodia; and India (ultimately) responded to an aerial bombing of its territory by Pakistan. This is not to say that none of these military actions were undertaken with humanitarian justifications, or that their consequences were not to improve the lives of at 
least some civilians in the targeted states; the claim is that all three actions were justified under existing rules of international law and did not require additional humanitarian rhetorical support or deviation from (or for some, improvement of) the law as it stands. The concern here is to employ these cases to stand for the proposition that since civilians were exposed to a range of inhumane acts in Uganda, Cambodia, and East Pakistan, that these military responses were justified as cases of humanitarian intervention; blithely ignoring the fact that they were in all three cases justified responses to aggression is tantamount not only to rewriting the facts, but to creating rights of military actions on the basis of precedents that do not quite justify them. In other words, and this is in any event the prevalent legal and moral argument today, states are justified in attacking, bombing, and invading others on the basis of humanitarian claims. Because Walzer does not think much of the United Nations' ability to provide "rescue and relief (Walzer, 2007, p. 253), it is up to those who can, to do it. Where does this leave the state? One could suppose that it depends on the state: some states have obligations to protect individuals abroad, while other states are argued out of existence, replaced instead by suffering individuals bearing rights to be rescued (Walzer, 2007, p. 253). Some states provide enforcement of rights for individuals on their territory-in fact, according to Walzer, what is unique to the state is "the description of rights enforcement as its central purpose" (Walzer, 2007, p. 260)-but in some cases, states, when they determine (on some good basis, but it is not quite certain what that would be, and how it is possible to always know for sure) that citizens of a foreign state are being massacred, have obligations to protect them, because no other entity can.

Analogies with domestic cases such as police are troublesome here because they fail to render the reality of international relations, or at best warp a proper analogy which would consider, for example, discretionary decisions of the police when to stop or not a speeding motorist ${ }^{4}$ as a decision made by some sort of police-like international entity, rather than by some state (presumably a powerful enough one). It makes a difference, when viewed domestically, whether one is stopped by the police-in which case one ought to accept the ticket or fight it in court-or by a burly motorist with a very powerful vehicle. In the latter case, not only is the legitimacy of the intervention highly questionable, but also what will come of it is unpredictable. In a civil society, it may be an unlawful act; in a Hobbesian state of nature, it looks like par for the course.

The difference, internationally - and the locus of the debate-is whether there exists anything tantamount to a police force, or a court, or some kind of locus of adjudication or of reasonable deliberation.

Kahn, too, has addressed the question and while less sanguine than Walzer about humanitarian intervention, he cannot articulate a reason why law-or antiquated arrangements at the U.N. level (antiquated presumably since they correspond to a coldwar logic) - ought to prevent states from ameliorating the lot of others (Kahn, 2000, pp. 51-53). The problem is not, in Kahn's view, a surfeit of questionable interventions, but rather the failure to carry out humanitarian intervention consistently around the world (Kahn, 2000, p. 57).

4 (Walzer, 2007, p. 250) responding to Edward Luttwack's objection that a rule fails to be moral if it is applied sometimes but not others. 
Moreover, it is difficult for Americans to adopt or ratify foreign or international human rights norms, as is evidenced by the exasperatingly slow pace of adoption of the Genocide Convention, the International Covenant on Civil and Political Rights, the additional protocols to the Geneva Conventions, the Convention on the Rights of the Child, and the Rome Treaty on the International Criminal Court. This is largely because, Kahn argues:

The United States was the first modern state, forming itself under a constitutional ideal of democracy and law. It is the country most deeply committed to an idea of itself as a sovereign entity under law. And it is the most spectacularly successful state in all of modern history. Only in the United States is the view deeply held that we have no need of the new global order of law: we have no such need because our nationalism has been a nationalism of rights under law for 200 years (Kahn, 2000, p. 59).

The expression of popular sovereignty accommodated itself well with the cold war arrangement, as it protected America's territory and political conception of the law (Kahn, 2000 , p. 57). It is the emerging project of global human rights that seems to disorient, though Kahn does not account for the fact that first, the human rights project-whether it be embodied by the United Nations, the International Covenant for Civil and Political Rights, or the Convention the Rights of the Child (to name only those) - is hardly an "emerging" cold war development. As for the post Cold-War human rights agenda, observers of international law can be forgiven for thinking that the vast majority of the initiatives to change the international landscape were American. The first Gulf War, the establishment of two ad hoc criminal courts in 1993 (ICTY) and 1994 (ICTR) (as well as hybrid courts subsequently), the NATO military campaign against rump Yugoslavia in 1999, and the unilateral war against Iraq in 2003 did more to vary the shape and content of the manner in which the international human rights project is advancing than any other initiatives since the Cold War's end.

Humanitarian intervention, too, is not something that was forced upon the United States; and it is not the invention of developing nations in the seventies. It represents something worth sacrificing life for, in Walzer's view, since it is an act of collective agency by the state, and though lives may be lost, the life of the state intervening is not at stake, it will live on (Walzer, 2007, p. 256). This argument appears to be meant to solve the "Good Samaritan" problem, that is the duty to help those whose lives are in danger, but not at the peril of one's own life. Walzer shifts the question by envisaging the action as not risking the intervening state's sovereignty or territorial integrity (Walzer, 2007, p. 256). This move, while reassuring states that understandably seek to preserve the lives of their own citizens ${ }^{5}$ - seeking, as Walzer puts it, zero casualties of their own (Walzer, 2007, p. 244), opens the question of what happens to the target state. Is its territorial integrity and sovereignty not in immediate peril? If such infringement of sovereignty is to be properly compared to the lives of individuals tasked to carry out humanitarian operations, then it may be worth wondering about whether any kind of fair procedural arrangement, or prior deliberation is not required before matters of such gravity are undertaken.

\footnotetext{
5 Yet in 1999 when many in the West defended the NATO's air war against Yugoslavia in moral terms, while fully acknowledging its illegality, Walzer was solitary the solitary voice in favor of ground war: "I was in favor of a ground invasion, because there would have been fewer casualties" (Brdar and Jokic, 2011, pp. 62-63).
} 
The sacrifice of individual lives, then, does not imperil the life of the state. The sacrifice is worthwhile as it is carried out on moral grounds, by this character, "we," to help "them". There is something disconcertingly similar in this assumption of sacrifice for the state (that will continue to live) to Kahn's more theological project, and his notion of sacrifice for the popular sovereign. There is something exceptional (or exceptionalist) in the view that "we," having determined that international regimes are ineffectual, or that human rights instruments cannot possibly apply to us (after all, didn't we write them in the first place?) ought nonetheless take justice into our own hands. What warrants this arrogance, this epistemic certainty (Jokic, 2004, p. 258)?

\section{The problem of legalism and the emergence of international criminal law}

The (usually, but not always) liberal commitment to legal principles has been described by political theorist Judith Shklar as "legalism" (Shklar, 1964; Bass, 2000, p. 20) that is "the ethical attitude that holds moral conduct to be a matter of rule following and moral relationships to consist of duties and rights determined by rules" (Shklar, 1964, p. 1). Legalism is a feature of most democratic societies, but can in addition constitute an ideology that denies "both the political provenance and the [political] import of judicial decisions" (Shklar, 1964, p. 1; Dossa, 1999, p. 73). Legalism illustrates the sort of formality that is required if judicial bodies established internationally (in the absence of supranational enforcement) are to be considered legitimate. In international relations theory, legalism is often contrasted to realism, which roughly holds that states exist in anarchy and cannot resort to established mechanisms of adjudication and must instead rely on self-help (Mégret, 2002, p. 1267; Bass, 2000, p. 276), or to idealism, which holdsmuch like Stone's concept of "normative rights" (Stone, 2002, p. 325)—that international criminal justice is a part of a movement toward "international idealism," according to which "normative structures can constrain state behavior, and that if we could get these normative structures built into the international system, the world would be a better place" (Goldsmith, and Krasner, 2003 quoted in Bibas and Burke-White, 2010, p. 641). Thus international criminal legal theory (as well as the international relations theory interested in the law) examines the political and normative tensions that emerge in rules and rights in a manner closely analogous to the approach in (Stone, 2002). It is worth noting, however, that legalism is both a tool of critical political analysis (as intended by Shklar) and a concept that has been reinterpreted by subsequent scholars and publicists as representing formalism as well as a (distinctively) liberal virtue (Bass, 2000, p. 6).

Despite previous well-meaning attempts, international criminal trials tasked with the prosecution of individuals only emerged with the Nuremberg Tribunal following the Nazi defeat after the Second World War (Maogoto, 2004, pp. 77-100; Power, 2002, pp. 49-50; Bibas and Burke-White, 2010. p. 646). Historical attempts to try Napoleon or Kaiser Wilhelm had failed (Bass, 2000, pp. 37, 106), confronted by international law's most enduring (and possibly intractable) problem, that is its continued existence in a virtual state of nature, without a supervening authority capable of pronouncing judicially and enforcing its authority against individual states exercising sovereignty (Kant, 1970, p. 103). Though this state of affairs did not genuinely change after the Second World War, 
and the formal arrangement of states remained one of anarchy (that is, without hierarchy of states), political will emerged strongly among the victorious Allied states to establish what Shklar calls "law-like political institutions" (Shklar, 1964, p. 156) to prosecute the Nazi leadership (as well as the Japanese) for the waging of aggressive war and for a newly promulgated offense called "Crimes against Humanity". Shklar recognized-much to the dismay of those most committed to the legalist nature of the Nuremberg and Tokyo trials-that the policy to try individuals was not a purely legal endeavor, emerging fullyformed from nowhere: it was a result of politics, meant to promote decent political aims. The work (Shklar,1964) examines the unexplored tensions (and indeed the paradoxes and conflicts) that were apparent in these trials. Seen in a purely legalist light, they could be said to enjoy great international legitimacy - to which (Stone, 2002, p. 300) would afford substantial weight, as legitimacy "magically" induces compliance in the polis-but that very same legalism paradoxically contributed to the erosion of the credibility of courts trying offenses that were not (at least technically) crimes at the time of their commission. And indeed, despite the establishment of the United Nations, not a single international criminal prosecution was carried out until after the cold war was over, with the establishment of the International Criminal Tribunal for the Former Yugoslavia in 1993 (Maogoto, 2004, p. 237; Bass, 2000, pp. 206-275). Thus, it cannot be said that Nuremberg left a truly legalist legacy in its wake: the cold war, witness to many large-scale atrocities and undeniably prosecutable war crimes, appeared to promote the interests of the two superpowers more than it did the pursuit of an international criminal policy agenda. As Geoffrey Best put it, as late as in 1984, Nuremberg was "but a beacon behind us, growing ever fainter" (Best, 1984, p. 26).

This is not only because there was still no supranational authority that could compel states (but most crucially the U.S. and U.S.S.R.) to submit to a judicial authority, but on broader philosophical grounds. Shklar contended that Nuremberg should be seen as the political conclusion of a kind of politics (Nazism and fascism) and of a kind of war (World War II). Viewed in that light, Nuremberg could never stand as a precedent (legal or otherwise) but as a sui generis resolution of an ideological war of elimination-on both sides-which demanded the corresponding elimination (albeit by legal, or at least legalistic means) of its defeated leadership (Shklar, 1964, p. 163). The trial was thus a policy vehicle established by the Allies to pose a specific political act, as opposed to a truly legal endeavor that could be referred to as having somehow modified the substance (and much less the nature) of international law. The value of Nuremberg was not, argues Shklar, that it recognized the legal force of the Hague Conventions (or anything else); it was that Nazi political behavior-and specifically what it consisted of - as well as the fact that the allies, however disproportionate were the military means they employed, say in the fire-bombing of Dresden, were not comparable to the atrocities committed by the Nazis. These actions could thus be the object of international political pedagogy, rather than constituting any kind of legal precedent. Here Shklar's analysis differs little from the Soviet view at the time as the "Russian archival record leaves no question that the Soviet regime and the secret Commission for Directing the Nuremberg Trials envisioned Nuremberg as a "show trial"- that is, as an exercise in didactic legalism" (Hirsh, 2008, p. 703). Furthermore, despite the important symbolic contribution of Nuremberg to the collective conscience (and it is worth noting that one need simply write the name of the 
city that housed the International Military Trial to evoke the triumph of Western-style law over barbarity and indeed evil) (Bass, 2000, pp. 204-5; and on symbolism Stone, 2002, pp. 145-6), its sister tribunal, Tokyo, did not benefit from such symbolic clarity.

In Tokyo, the political lessons made out with such eloquence against the Nazileadership hardly could have convinced the Japanese. They did not even persuade all the judges, and the dissent of Indian judge Radhabinod Pal in particular illustrates how different Tokyo was (Sellars, 2010, p. 1094). First, the "clean hands" of the Allies were much less apparent than in Nuremberg. As Bruno Simma noted in 1999: "Auschwitz was singularly German, and none of the offences committed by the Japanese political and military leaders came even close" (Simma, 1999, p. 83). Judge Pal was revolted that the Americans would try Japan for war crimes and crimes against humanity after Hiroshima and Nagasaki: and indeed, such outrageous hypocrisy (Shklar, 1964, p. 161; Pal, 1953, pp. 620-21) not only distinguished the lesson of Nuremberg from Tokyo's "political catastrophe," but it served to diminish the legal credibility of both bodies, when taken together. The lack of legitimacy of at least one of the two institutions diminished (as Stone would have predicted) chances of compliance following the end of the post-war proceedings.

Shklar's emphasis on the political benefits of legalism corresponds to a market/polis paradox where legalism stands in for the market's formalism and where international politics explain (and drive) what is required by the mechanics and nature of the international polis, or cosmopolis. Thus, Shklar's approach-dovetailing with Stone's-answers Richard Falk's query as to "why sovereign states should have been ever willing to validate such a subversive idea as that of international criminal accountability of leaders for war crimes". This validation, pursued Falk, only made sense "if the imposition of accountability is understood to be a particularly advantageous response to a given geopolitical challenge whose wider implications can be avoided" (Falk, 1999, p. 710). So, too, in the cosmopolis, politics, however less tidy than law or formal economic models, matter.

Legalism was meant as a conceptual device serving precisely to illustrate the necessity of political will in the emergence of international criminal law. ${ }^{6}$ With the establishment of two ad hoc institutions trying individuals by the United Nations Security Council, as well as the nascent International Criminal Court (of which the US is not a member state, and whose jurisdiction it continues to oppose), ${ }^{7}$ legalism continues to provide analytical guidance analogous to Stone's view of rights as "a more diffuse method of articulating standards of behavior in an ongoing system of conflict resolution" (Stone, 2002, p. 325).

In international relations, it is this very "ongoing system of conflict resolution" that demands a more sophisticated analysis, allowing for an examination of degrees of legalism, as well as a respect for democratic choices made by different societies along a continuum ranging from international regimes demanding formal accountability and retribution, to collective political responsibility and reconciliation (Kahn, 2000b, p. 5). Snyder and Vinjamuri argue that the realization of social peace in post-conflict states is often owed to the decision to defer immediate justice to political negotiations (Snyder, and Vinjamuri, 2003, p. 13). Moreover, the deterrent effect of justice can be significantly limited when a

\footnotetext{
${ }^{6}$ For a recent detailed discussion of Shklar's concept of 'legalism' (see Dickson, 2015).

7 See 'National Security Strategy' (2010), p. 48, available at https://www.whitehouse.gov/sites/default/files/rss_viewer/national_security_strategy.pdf (last visited 17 December 2015).
} 
society is trapped in a perverse-equilibrium — a situation in which individuals are unwilling to stop abusive practices unless everyone credibly commits to ending them (Katzenstein, and Snyder, 2009, pp. 59,63). Overcoming these challenges often requires providing amnesties, and bargaining with key leaders of the previous regime who otherwise may be inclined to derail the process of post-conflict institution building. The South African Truth and Reconciliation Commission, and the amnesties granted by Spain in order to confront its fascist past-the latter should be of interest in light of Spain's attempts to prosecute Augusto Pinochet despite Chile's political decision to grant him immunity as a senator (Rodman, 2006, p. 25) - constitute recent examples of non-legalistic approaches to addressing problems of political transition.

It is possible to doubt the transformative effects of international norms. Particularly in international politics, when legalism clashes with the demands of politics, prudence may guide national leaders toward the latter. In an international environment in which "there are many demands, multiple norms, power asymmetries, and no authoritative decisionmaking structures," states are socialized to international norms and values imperfectly (Krasner, 1999, p. 9).

\section{The paradox of the illiberal individual}

If international law is indeed moving from, as Kahn puts it, "a doctrine of state relations to a regime of individual rights" (Kahn, 2000b, p. 5), this will likely lead to a highly individualized self-conception where rights-even internationally-precede other political commitments. Yet political commitments range more widely than merely to rights: families, community, the popular sovereign, and institutions of non-domination or of deliberation. Even if commitments do not-or ought not-extend that far, if they are political by nature, they cannot be reduced to a narrow individual conception of rights without changing something fundamental in the nature of the liberal view. However important the law, procedure, and rights are to liberalism, on any account, they are important within institutions of the state. That is where these commitments emerge as politics, and it is in state institutions (whether those of deliberation or those of justice) that these liberal commitments thrive. In the continued absence of a truly genuine (that is universal) international enforcement of justice, the idea of a regime of individual rights replacing a doctrine of state relations is not only implausible, but seems, as it would reintroduce a kind of pre-political anarchy, simply illiberal. Surely this is not the polis that liberal opponents of sovereignty would wish upon themselves. 
Тифејн Л. Диксон ${ }^{1}$

Државни универзитет у Портланду

Марк О. Хетфилг Факултет за управу

Одсек за политичке науке

Портланд (Орегон, САД)

\title{
МИ, НАРОД И СВЕТ: \\ ПРОБЛЕМАТИЧНИ ОДНОС АМЕРИЧКОГ ЛИБЕРАЛИЗМА И МЕЂУНАРОДНОГ ПРАВА ${ }^{2}$
}

\author{
(Превоg In Extenso)
}

Сажетак: Улога коју у друштву игра право од централног је значаја у свакој верзији либералне теорије. Колико од да је тешко обезбедити сагласност у погледу онтолошке природе и епистемолошких зактева које либерална теорија поставља пред закондавство, тешкоће се увелико умножавају када либерална теорија треба да се примени на случај међунароних односа. Ситуација која ствара највећи проблем либералној теорији је када појам правде треба применити ван територијалних граница модерне суверене државе, пошто не постоји међународни судија који би непристрасно и несумњиво разрешавао спорове. Супротно идеалима многих либералних мислилаца, сила и даље ужива врховну моћ у односима између држава, а то је као реалност тешко ускладити с легалистичким либерализмом као теоријском позицијом.

Кључне речи: Либерализам, међународно право, суверенитет, хуманитарна интервенција, Нирнберг .

Тешко је наићи на приказ либерализма - било да је аутор његов заговорник или критичар - а да он не наводи као један од његових најзначајнијих ставки владавину права, ако не и као његову централну карактеристику /тог теоријског приступа. Било да се владавина права појављује као морална дужност да се несретни чланови неке територијално дефинисане групе извуку из природног стања и преведу у цивилно друштво засновано на аутономији и слободи, као што је случај са Кантовом верзијом у интерпретацији Ане Стилз (Anna Stilz); као административни процес који треба да буде обележен пажљиво осмишљеним демократским делибиративним расуђивањем, као код Хенрија С. Ричардсона (Henry S. Richardson); као

\footnotetext{
1 tiphaine@pdx.edu

2 Овај чланак се заснива на истраживању које је извршено ради израде дисертације под насловом „О сиромаштву, порасту и смрти међународног кривичног права”, одбрањене на Државном универзитету Портланд 16. марта 2016. године.
} 
фетишизовано место политичко-теолошког пројекта, приказаног у облику заснивајућег мита у интерпретацији Пола Кана (Paul Kahn); или алтернативно, као симптом пребацивања с ограничености суверенитета на укрупњавање путем воље, сходно твђењу Џин Бетке Елстеин (Jean Bethke Elstain); или, на крају, као нужног зла, које треба гледати с демократском опрезношћу и солидном дозом плуралистичког скептицизма, као код Мајкла Волцера (Michael Walzer), право je, без обзира на његову варијабилност, увек од велике важности (Shklar, 1964; Stilz, 2009; Richardson, 2002; Elshtain, 2008; Kahn, 2005; Walzer, 2007).

Колико год да је тешко постићи сагласност у погледу онтолошке природе и епистемолошких захтева либералне позиције у у односу на право, изазови који се постављају пред либералну идеју законитости увелико се увећавају када се разматра као међународни феномен. Није случајно што је Склар (Shklar, 1964) узела да пише о процесима у Нирмбергу и Токију. Управо када се правда разматра изван територијалних граница суверене државе, либералима се проблеми појављују у свој својој оштрини. То је зато - како то Ана Стилз добро зна мада на то не ставља нагласак - што Кантова процена, дата у Вечном миру (Kant, 1970), да се међународни односи још увек одвијају у природном стању, што тек треба да се промени, без обзира на сва позивања на морално право на интервенцију (Walzer, 2007) која су све гласнија. Кант и данас није далеко од истине када каже да државе „немају спољашњи трибунал пред којим би се о њиховим захтевима пресуђивало” (Kant, 1970, str. 104), пошто такви судови, који по природи ствари морају имати моћ да наметну извршења својих сопствених одлука, и даље не постоје кад је реч о односима на међународном нивоу. ${ }^{3}$ Правна тела су, међутим, успешно успостављена од стране Савета безбедности уједињаних нација и Римског статута, и ови судови - или „законолика политичка тела” како их назива Џудит Склар (Shklar, 1964, str. 156) - имају надлежности над појединцима. Проблем је у томе што ова тела имају (апсолутну) јурисдикцију само у погледу појединаца који припадају нацијама које нису стални чланови Савета безбедности, и који не могу сами да успоставе ad hoc судове, или које - што је много важније - нису довољно моћне да одбију јурисдикцију трибунала као што је Међународни кривични суд (ICC) тако што би, на пример, одлучиле да ставе вето и спрече упућивање на истраге које се тичу њихових грађана.

Неколико питања се, дакле, намећу на које либерали треба да одговоре. Међународна правда - или прецизније речено, међународно право - када се прикаже на овакав недвосмислен начин, може да делује у многоме прилично нелиберално. Прво, недоследна примена закона наизглед крши принципе једнакости и правичности. Недостатак универзалности у примени репресивног механизама међународног кривичног права сугерише да би процес могао да буде арбитраран, да се у својој примени заснива на недоследним проценама, и што још више забрињава, да је процес подложан утицају моћи у недопустивој мери, а то нарушава дубоку либералну

3 По члану 36 Статута Међународног суда правде (ICJ), суд нема јурисдикцију над споровима када недостаје сагланост држава којих се спор тиче. Видети „Case of the Monetary Gold Removal from Rome in 1943 (Preliminary Question), Judgment of June 15 $5^{\text {th }} 1954$ ”: I.C.J. Reports 1954, str. 19. Кад је ІСЈ инсистирао на сагласности, државе, укључујући САД, су једноставно одбијале да учесвују у прелиминарној фази суђења (в. Charney, 1987; и такође Kahn 2000a, str. 35). 
приврженост принципу једнакости. Друго, мера у којој политика (у овом случају, међународна политика) има утицај у одређивању ситуација у којима ће се судити (или интервенисати) делује далеко од типа рационално заснованог процедуралног механизма коме су либерали привржени када ствари треба решавати на правни начин или на суду.

Најзад, моћ има много већи утицај у одређивању шта (или ко) ће бити или неће бити подвргнут преиспитивању пред међународним „законоликим политичким телима" него што би либерали могли комотно да подрже. Ова последња поента коегзистира с понекад нелагодним либералним погледом на суверенитет, пошто управо ова идеја омогућава и оправдава, бар што се тиче неких светских сила, да уживају имунитет од кривичног гоњења; овај исти појам је виђен (често од стране оних истих држава које се на њега позивају када треба заштитити сопствене интересе) као банална правоверност једног прохујалог времена-или бар као нешто сто у екстремним случајевима има контрапротивну, ако не и нескривено опасну улогу у међунароном амбијенту после Хладног рата.

Исходиште ових питања је потреба да се зна која је то врста преступа која би оправдавала међународну правну интервенцију, и посебно постоји ли било каква (либерална) основа за тврдњу да појединци могу потраживати право да буду заштићени од таквих неправди, или пак, што је овде од још већег значаја, право (или обавезу) држава да интервенишу у име ових индивидуа када су оне грађани страних држава, на туђој територији, те према томе подложне закону једне друге јурисдикције (Walzer, 2007, str. 255). Стога, грубо формулисано, да ли смо зарад остварења овог циља спремни да убијамо или да жртвујемо сопствене животе (Walzer, 2007, str. 256)?

Либерали ће се такође заинтересовати на који начин тачно настају међународна права, обавезе, процедуре и институције; приврженост либералним идеалима придаје одређену важност природи споразума који намећу обавезе, стварају законе (без обзира да ли се они могу утеривати или не), и у екстремним случајевима, омогућавају да се појединцима ускрати слобода - као што је то било у случајевима сталног или ad hoc кривичних судова, односно суђења за ратне злочине - или пак да се крене у рат, што најчешће појединце лишава живота, како међу својим сународницима тако и људи који живе у другим државама.

У овом есеју бавимо се овим широко схваћеним проблемима у њиховом историјском контексту и разматраћемо их у светлу тога како су одређени савремени либерали (и неки од њихових критичара) њима приступали. Основна пажња биће дата питањима међународног прва и нарочито томе како овај тип нормативноости либерализам суочава с посебним тешкоћама.

\section{Суверенитет}

У оваквом стању ствари, може да изгледа примамљиво да се окриви сама појава суверености, пошто се потраживања права не могу потпуно и непристрасно правно разматрати и пресуђивати на једнак начин против свих, или пак као сам узрок неконтролисаног ратовања и огромног броја злочина почињених од стране држава. Међутим, пре него што разматримо за шта се суверенитет стварно може 
оптужити, вреди прво покушати да видимо шта је заправо сувереност (и наспрам чега се одређује). Ово је наравно врло тешко питање, а покушаји да се суверенитет дефинише разликоваће се по својој јаснћи и квалитету од једног до другог теоретичара и зависиће од њихових онтолишких и политичких ставова. Пол Кан описује нешто што означава као упечатљиво америчко виђење (Kahn, 2005) по коме примат има народна сувереност из које закон изводи свој легитимитет, а не супротно томе, како наводе други теоретичари, по којима закон претходи суверености и при том је ограничава (Kahn, 2005, str. 58). То је оно „ми, народ”, што се по Кановом мишљењу не односи на просту владавину већине; уместо тога, ради се о народном суверенитету као транс-историјском процесу током којег сам народ себе ствара и одржава (Kahn, 2005, str. 13). Ово очигледно није захтевано од оне врсте на коју би се држава, сходно неком правном гледишту, могла позвати противећи се нападу или наметању које долази споља. Тврдње о ономе што можемо назвати културним суверенитетом носи непријатно блиску сличност са тврдњама о ексцепционализму (Kahn, 2010), а сам Кан се није устручавао од импликације да је ексцепционализам [појам се односи на идеју да су САД посебна држава утолико што чини планетарно добро услед чега правила која сви други морају да следе, на важе за САД које су уникатан изузетак -йpuм. üpeв.] америчког типа лако уочљив и из иностранства - од посебног значаја за тему овог есеја која се тиче неспремности САД да буду подвргнуте Међународном кривичном суду (Kahn, 2003) - као израз голог интереса једине суперсиле. Но. пошто идеја америчког ексцепционализма, за више од двеста година претходи стању САД као суперсиле, оправдање за то мора се тражити на другој страни. Очито, по Кановом мишљењу, то није само пуко питање моћи. Нити је амерички ексцепционализам заснован на разматрању појма праведности, пошто гледиште да уредбе међународног права треба да важе за све државе осим за САД - то је сасвим јасно - није оно које се наметнуло на основу расуђивања иза вела незнања (Kahn, 2010). Томе насупрот, ексцепционализам се на уверљивији начин може оправдавати чињеницом да амерички народни суверен наступа и говори искључиво кроз закон (Kahn, 2005, str. 20-21). „У том тренутку, пише Кан, „изузетак постаје изузетан, као шти је случај с америчким екцепционализмаом” (Kahn, 2010). Позивање на „изузетак” овде експлицитно (и на донекле уземирујићи начин) упућује на Карла Шмита (Karl Schmitt), теротичара којим се Кан бавио у свом недавном делу (Kahn, 2011). Иако је јасно назначио да жели да доведе „либерализам у везу са Шмитом” а не да усвоји његове антилибералне погледе - посебно не његово виђење које се тиче утемељивања суверенитета у предполитичкој концепцији „суштинске хомогености народа” (Kahn, 2011, str. 20) - Кан је, ипак, преузео шмитовску теоријску конструкцију да би расправљао о нечему што означава као виђење америчке политичке вере у народну сувереност, која у конретном случају иде тачно насупрот виђењу које претпоставља да је хомогеност народа од суштинке важности, захтевајући уместо тога да се народни суверенитет уклопи у разноликост имигрантских група и најразличитијих вера.

Иако овакво разумевање ексцепционализма нуди објашњење квазирелигијске преданости суверенитету САД, као одраза америчког идентитета и оправдања за жртвовање, оно ипак ничим не омогућава, а још мање оправдава, амерички (или либерални) однос према суверенитету других држава. Наиме, да ли је пука чиње- 


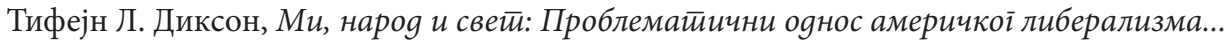

ница ексцепционализма довољна да би нека држава држала друге под обавезом да поштују норме док истовремено себе штити од институционализованог утеривања тих истих правила?

\section{Хуманитарна интервенција}

Овде се можемо позвати на опис Мајкла Волзера (Michael Walzer), мада када се узме у овом контексту може да се чини као да се он превише ослања на силу. По питању хуманитарне интервенције Валзер инсистира да суочени с почињеним и текућим зверствима, треба да интервенишу они који су то у стању - а под интервенцијом он подразумева употребу војне силе. Како би предупредио импликацију да овај морални суд опуномоћује моћне и просвећене (често користећи реч „ми” за коју Џудит Склар казе да су ти „'ми’ његови омиљени ликови” (Shklar, 1998, str. 379) који се понашају у стилу осветника с Дивљег запада, Волзер се позива на три примера које можемо назвати хуманитарним интервенцијама из „Трећег света” како би показао да је понекад „географска близина” оно „може” које се претвара у „треба” (Walzer, 2007, str. 255), а што представља врсту способности да се реагује, која сама од себе производи обавезу да се то и учини. Проблем са случајевима које он наводи - а што указује на шири проблем утеривања правде путем кажњавања војним средствима без консултовања неке правне институције која би била у стању да одмери ваљаност разлога за акцију и успешно разликује чињенице од реторике, макар колико она била добронамерна - садржан је у томе што се све три „хуманитарне интервенције” могу убедљиво оправдавати као одговори на агресију.

Танзанија је одбила трупе Уганде које су нелегално биле на њеној територији (за коју је Уганда претендовала да јој припада); Вијетнам је одговорио на учестале агресије све осорније Камбоџе; док је Индија (на крају) узвратила на бомбардовања своје територије из ваздуха од стране Пакистана. Ово међутим не значи да ове војне акција нису биле предузете уз хуманитарно оправдање, нити да њене последице нису биле срачунате на побољшавање животних услова бар неког дела цивилног становништва у нападнутим државама; напротив, овде се просто тврди да су све три војне акције биле оправдане на основу йосйојећих йравила међународног права и да није било потребе за додатном хуманитарно-реторичком потпором или пак одступања (или како неки мисле усавршавања) тог права онаквог какво јесте. Овде је реч о томе да се ти случајеви, пошто су цивили у Уганди, Камбоџи и Источном Пакистану били изложени нехуманим поступцима, искористе у прилог тезе о оправданости тих војних одговора као случајева хуманитарне интервенције; олако игноришући чињеницу да се у сва три случаја радило о оправданим одговорима на агресију, било је не само исто што и преаранжирање чињеница већ и измишљању оправданости војних акција на основу изузетака/прецендената којима се баш не могу оправдати. Другим речима, а то је данас преовлађујући правни и морални аргумент, државе оправдано нападају, бомбардују и врше инвазију других земаља на основу хуманитарних норми. Пошто Волзер углавном не мисли на способност Уједињених нација да обезбеде „спас и одмор” (Walzer, 2007, str. 253), онда то, по њему, зависи од оних који су то у стању да обезбеде. Како у том погледу стоји с овлашћењем државе? Може се претпоставити да то зависи од државе до држа- 
ве: неке имају обавезу да заштите појединце у иностранству, док у случају других, изопштених, појединци пате мада имају права да буду спасени (Walzer, 2007, str. 253). Неке државе обезбеђују појачање права индивидуа на својој територији - у ствари, према Волзеру, за државу је јединствен „опис правне принуде као њена основна сврха" (Walzer, 2007, str. 260) - док у неким случајевима државе, пошто одреде (на некој основи, само што није извесно да ће тако увек бити, као што је неизвесно то знати са извесношћу) да се над грађанима стране државе спроводи масакр, имају обавезу да их заштите, зато што то нико други није у стању.

Аналогија с домаћим случајевима као што је полиција, овде је непримерена с обзиром да она нема овлашћења у сфери међународних односа, да бисмо у најбољем према грубој аналогији размотрили, на пример, дискрециону одлуку полиције по питању да ли ће или не зауставити мотоцикисту због пребрзе вожње, ${ }^{4}$ у смислу одлуке неке врсте међународног ентитета налик полицији, пре него од стране неке државе (првенствено оне која је довољно моћна). Постоји разлика, када гледано у оквиру државе, имамо дилему да ли да возача заустави полиција - у ком случају следи казна или судски спор - или да то учини огроман мотоциклиста с врло моћном машином. У овом другом случају, не само што је дубоко спорна легитимност интервенције, него је такође непредвидљиво шта из тога може да произађе. У грађанском друштву то може да буде незаконит поступак; у хобзовском природном стању је сасвим уобичајено.

Проблем на међународном плану - и језгро расправе - је у томе постоји ли у односу на полицију нека виша инстанца, суд, или неко место просуђивања и разложног разматрања.

Кан се такође позабавио овим питањем и мада у мирнијем тону од Волзера по питању хуманитарне интервенције, није могао да артикулише разлог зашто закон - или застарели аргументи на нивоу УН (застарели првенствено зато што су у складу с хладноратовском логиком) - треба да /спречава поправљање стања у другим државама (Kahn, 2000, str. 51-53). Проблем није, према Кановом гледишту, у претераном броју спорних интервенција, него у грешци што се оне конзистентно не изводе широм света (Kahn, 2000, str. 57).

Надаље, Американцима је тешко да прихвате или ратификују међународне норме људских права, што се осведочава у изузетно спором процесу прихватања Конвенције о геноциду, Међународног споразума о грађанским и политичким правима, додатних протокола Женевској конвенцији, Конвенцији о правима детета, и Римског уговора о међународним кривичним судовима. То је, како Кан тврди, углавном зато што су Сједињене Државе:

„прва модерна држава која се формирала под уставним идеалом демократије и права. То је држава најдубље привржена идеји о себи као сувереном ентитету под владавином права. И то је најспектакуларније успешна држава у модерној историји. Само у САД је дубоко прихваћено гледиште да немамо потребу за новим глобалним правним поретком: такву потребу немамо пошто наш национализам већ 200 година представља национализам права под владавином закона" (Kahn, 2000, str. 59).

4 (Walzer, 2007, str. 250) у одговору на примедбе Едварда Лутвека (Edward Luttwack) да владавина престаје да буде морална ако се примењује само на неке, а не на све случајеве. 
Тифејн Л. Диксон, Ми, нароg и свети: Проблемайични оgнос америчкой либерализма...

Изражавање народног суверенитета прилагођава се стању Хладног рата, саобразно заштити америчке територијалне и политичке концепције права (Kahn, 2000, str. 57). Настајући пројект глобалних људских права који чини се дезоријентише/ ремети, мада Кан не објашњава чињеницу, први пројект људских права - било да је отеловљен у УН, Међународном споразуму за грађанска и политичка права, или Конвенцији о правима детета (да споменемо само њих) - тешко да се може разумети као део „настајућег” хладноратовског развоја. Што се тиче агенде људских права после Хладног рата, посматрачима међународног права може се опростити због мишљења да је већину иницијатива за промену међународног пејзажа дају Американци. Први Заливски рат, успостава два ad hoc кривична суда 1993. (ICTY) и 1994. (ICTR) (као и хибридних судова потом), НАТО кампања против Југославије 1999. и унилатерални рат против Ирака 2003. водили су промени облика и садржаја начина на који се пројект људских права на међународној сцени унапређује више него било која иницијатива од краја Хладног рата.

Хуманитарна интервенција такође није нешто наметнуто Сједињеним Државама и није изум земаља у развоју током седамдесетих година. Она представља нешто вредно жртвовања живота, по Волзеровом гледишту, пошто представља акт колективног агенса од стране државе, и мада је могућ губитак живота, није на коцки живот државе која интервенише, која ће наставити да живи (Walzer, 2007, str. 256). Изгледа да овај аргумент може да послужи за решавање проблема „доброг Самарићанина", тј. дужности да се помогне онима чији животи су у опасности, али да то не буде на штету личног живота онога ко прискаче у помоћ. Вплзер помера питање предочавањем акције као безопасне по суверенитет и територијални интегритет државе у којој се интервенише (Walzer, 2007, str. 256). Тај потез, којим уверава државе које разумљиво гледају да заштите животе својих грађана ${ }^{5}$ - који тражи, како каже Волзер, одсуство жртава (нулто стање штете) (Walzer, 2007, str. 244) поставља питање о томе шта се догађа циљној држави. Није ли она у опасности због самог територијалног интегритета и суверенитета до којих држи? Ако такво нарушавање суверенитета преба ваљано да се упореди са животима оних који су задужени да интервенцију изведу, онда има вредност чуђење/питање о томе није ли пре него се предузме акција такве тежине неопходан фер аранжман било која врста процедуралне врсте или претходно промишљање саме акције.

Жртвовање живота појединаца, дакле, не штети животу државе. Жртвовање има вредност уколико је изведено на моралој основи, карактеризацијом „нас” („ми”) који помежемо „њима”. Има у тој тврдњи о жртвовању за државу (која ће наставити да живи) нечега забрињавајуће сличног Кановом више теолошком пројекту, и његовом појму жртвовања за народног суверена. Има нечега изузетног (или ексцепционалистичког) у гледишту да „ми”, пошто смо утврдили да је међународни поредак немоћан, или да се на нас не могу применити инструменти људских права (најзад, нисмо ли их ми написали?) ипак требада правду узмемо у своје руке. Међутим, где су гаранције за ту ароганцију, ту епистемичку извесност (Jokic, 2004, str. 258)?

\footnotetext{
5 Ипак 1999. када су многи на Западу бранили НАТО рат против Југославије на моралан начин, мада су у потпуности били свесни његове нелегалности, Валзер је био усамљен у заступању копнене интервенције: „Био сам за конпнену инвазију, пошто иста не би имала много жртава”, (како је цит. и дискутовано у Brdar and Jokic, 2011, str. 62-63).
} 


\section{Проблем легализма и настанка међународног права}

Либералну приврженост правним принципима (уобичајено, а не увек) политички теоретичар као што је Џудит Склар описује као „легализам” (Shklar, 1964; Bass, 2000, str. 20) то јест као „етички став који држи да је морално понашање ствар правила које се следи и моралних односа сачињених од дужности и права која су пдређена правилима" (Shklar, 1964, str. 1). Легализам је одлика већине демократских друштава, а уз то може да сачињава и идеологију која оспорава „политичко порекло и [политички] импорт правних одлука” (Shklar, 1964, str. 1; Dossa, 1999, str. 73). Легализам илуструје врсту формализма који је неопходан када се правна тела образована на међународном плану (у одсуству наднационалне принуде) да би била оцењивана као легитимна. У теорији међународних односа легализам се често супротставља реализму који грубо тврди да држава постоји у анархији и да не може да прибегава успостављеним механизмима пресуђивања инего уместо тога мора да се ослони на самопомоћ (Mégret, 2002, str. 1267; Bass, 2000, str. 276), или на идеализам који -- слично Стоновом концепту „нормативних права” (Stone, 2002, str. 325) -тврди да је кривични међународни суд део покрета ка „међународном идеализму”, према којем „нормативне структуре могу да воде ограничењима понашања државе и ако нам пође за руком да те структуре уградимо у систем међународних односа свет би био боље место за живот" (Goldsmith, and Krasner, 2003 quoted in Bibas and Burke-White, 2010, str. 641).

Та теорија међународног кривичног права (као и теорија међународних односа заинтересована за право) испитује политичке и нормативне напоне који се јављају у примени правила и права на начин врло сличан у приступу (Stone, 2002). Међутим, нема значаја то што је легализам истовремено оруђе критичке политичке анализе (као што је то у случају Склерове) и концепткоји се реинтерпретира од стране потоњих учењака и публициста који заступају формализам заједно с (одређеном) либералном врлином (Bass, 2000, str. 6).

Упркос ранијим добро осмишљеним настојањима, процеси пред међународним кривичним судом задуженим за процесуирање појединаца појавили су се са судом у Нирнбергу, после пораза нациста у II светском рату (Maogoto, 2004, str. 77-100; Power, 2002, str. 49-50; Bibas and Burke-White 2010, str. 646). Историјски покушаји да се суди Наполеону или Кајзеру Вилхелму остали су неуспешни (Bass, 2000, str. 37, 106), у суочењу с најтрајнијим (и најтврдокорнијим) проблемом међународног права, то јест његовим континуираним постојањем у виртуалном природном стању услед недостатка надређеног ауторитета који би био у стању да изрекне пресуду и наметне је насупрот појединим сувереним државама (Kant, 1970, str. 103). Пошто се то стање није много изменило после II светског рата, и формално стање међу државама и даље карактерише анархија (тј, одсуство хијерархије држава), међу победничким државама Савезника јавила се политичка воља за успоставом онога што Склерова назива „законоликим политичким институцијама” (Shklar, 1964, str. 156) за процесуирање нацистичких и јапанских вођа због покретања агресивног рата и за новоуведен прекршај зван „злочин против човечности”. Склерова признаје - умногоме зарад пораза оних који држе до легалистичке природе нирнбершких и токијских процеса - да настојање да се суди појединцима није баш правно чи- 
сто, пошто је у пуној мери настало ниоткуда: као резултат политике, с намером промоције пристојних политичких циљева.

У свом раду (Shklar, 1964) Скларова испитује неиспитане тензије (парадоксе и сукобе) који су дошли до изражаја током суђења. Гледано у чисто правном светлу, могло би се рећи да они уживају велик степен међународне легитимности - којој (Stone, 2002, str. 300) припада одговарајућа тежина, као што легитимност „магично” подразумева приврженост полису - али да исти тај легализам парадоксално својим радом истовремено доприноси ерозији кредибилитета судова који се баве прекршајима који (барем технички гледано) нису злочини. И заиста, упркос формирању Уједињених нација, пре окончања Хладног рада није изведен ни један судски процес пред међународним кривичним судом, све до успоставе Међународног кривичног трибунала за бившу Југославију 1993. (Maogoto, 2004, str. 237; Bass, 2000, str. 206-275). Према томе, не може се рећи да да је Нирнберг оставио труло правно наслеђе у свом повоју: Хладни рат је осведочио многе велика зверства која би несумњиво могла да буду предмет као ратни злочини, у интересу промоције интереса двеју суперсила више него што је то учињено агендом међународног кривичног права. Као што је рекао Џорџ Бест, 1984, Нирнберг нам је био „светионик за леђима који је растом постајао све неодређенији” (Best, 1984, str. 26).

Стање није такво само због одсуства наднационалног ауторитета који би могао државе да принуди (најпре САД и СССР) да се потчине ауторитету права, него и из шире филозофских разлога. Склерова тврди да Нирнберг треба разумети као политички закључак политике одређене врсте (нацизма и фашизма) и врсте рата (II светског рата). У том светлу Нирнберг се не може ценити као изузетак (правни или који други), већ као sui generis одлука идеолошког рата елиминације - на обе стране - који налаже одговарајућу елиминацију (додуше правним или бар легалистичким средствима) - његовог пораженог вођства (Shklar, 1964, str. 163). На тај начин, суђење је било политичко средство Савезника да успоставе такав политички акт који, као супротстављен чисто правном процесу, може да се узме као случај који на неки начин модификује/мења супстанцу међународног права. Вредност Нирнберга, како тврди Скларова, није у признавању силе права према Хашкој конвенцији (или било чега сличног); него је нацистичко политичко понашање - а нарочито оно што је улазило у његов састав - као и чињеница да Савезници, без обзира на несразмерно употребљена ратна средстава, на пример у бомбардовању Дрездена, нису упоредива с нацистичким злочинима. На тај начин, ти поступци могу да буду предмет међународне политичке педагогије, пре него да сачињавају неку врсту правног изузетка. Овде се анализе Склерове донекле разликује од совјетског гледишта тог времена пошто „руски архивски записници не остављају места за сумњу да су совјетски режим и Тајна комисија за вођење Нирнбершких процеса Нирнберг видели као „монтирани процес” - то јест, као вежбу из дидактичког легализма" (Hirsh, 2008, str. 703). Надаље, упркос важном симболичком доприносу Нирнберга колективној савести - а вредно је помена да је довољно написати име града домаћина Међународног ратног трибунала, да се оживи тријумф западног права над варварством и несумњивим злом (Bass, 2000, str. 204-5 - and on symbolism Stone, 2002, str. 145-6), трибунал исте врсте, онај у Токију, није толико симболички добио од такве симболичке јасноће. 
Што се токијског трибунала тиче, политичке лекције изведене таквом елоквенцијом као противу нациста, Јапанцима не би биле убедљиве. Оне нису убедиле ни већину судија, и дисидент, индијски судија Radhabinod Pal посебно је илустровао колико је Токијо био друкчији (Sellars, 2010, str. 1094). Најпре, „чисте руке” Савезника биле су много нејасније него у случају Нирнберга. Као што је записао Бруно Сима 1999: „Аушвиц је био само немачки, и с тиме не може да се мери ни један прекршај који су починили јапански политички и војни лидери” (Simma, 1999, str. 83). Судија Пал је био револтиран што Американци суде Јапану за ратне злочине против човечности после Хирошиме и Нагасакија; и заиста, таква нечувена хипокризија (Shklar, 1964, str. 161; Pal, 1953, str. 620-21) није само раздвајала лекције Нирнберга од токијске „политичке катастрофе”, него је послужила умањењу правног кредибилитета обеју страна. Недостатак легитимности барем једне од тих двеју институција умањила је (као што је предвидео Стон) изгледе повиновања одлукама послератних судских процеса.

Скларова указује да политичке користи од легализма кореспондирају парадоксу тржиште-полис, где легализам иде скупа с тржиштем и где се легализам саглашава с тржишним формализмом а међународна политика објашњава шта налаже механизам природе међународног полиса, космополиса. На тај начин, приступ Скларове - у складу са Стоновим - даје одговор на питање Ричарда Фалка (Richard Falk) „зашто суверене државе увек придају вредност тако субверзивним идејама као што је идеја међународног кривичне одговорности лидера за ратне злочине”. То вредновање, тврди Фалк, има смисла једино „ако је наметање одговорности

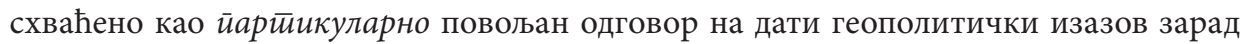
избегавања његових ширих последица” (Falk, 1999, str. 710). То ce, у космополису, политици, односи далеко мање чисто него што је случај са правом или формалним економским моделима.

Легализам је био замишљен као концептуално средство да илуструје неопход-

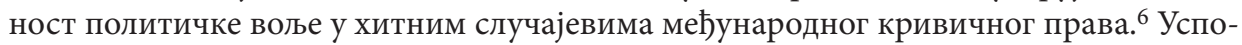
ставом од стране Савета безбедности УН два поменута ad hoc кривична суда која процесуирају појединце, као и новоформиран Међународни кривични суд (којег САД нису држава чланица, и чијој јурисдикцији наставља да се противи), ${ }^{7}$ легализам и даље обезбеђује аналитичко упутство аналогно Стоновом схватању права као „дифузнијој методи артикулисања стандарда понашања у датом систему разрешавања сукоба" (Stone, 2002, str. 325).

У међународним односима управо тај „актуелни систем решавања сукоба” налаже много детаљнију анализу, која би укључила испитивање степена легализма, као и уважавање демократских избора начињених од стране различитих друштава уздуж континуума који иде од међународних режима који укључују формалну одговорност и одмазду, до колективне политичке одговорности и помирења (Kahn, 2000b, str. 5). Снајдер и Вињамури тврде да се остварење друштвеног мира у пост-конфликтним државама често дугује одлуци да се непосредно задовољење

\footnotetext{
6 За новије детаљније дискусије везане за концепт „легализма” Склерове (в. Dickson, 2015).

7 Вид. 'National Security Strategy' (2010), p. 48, доступно на https://www.whitehouse.gov/sites/ default/files/rss_viewer/national_security_strategy.pdf (last visited 17 December 2015).
} 
правде замени политичким преговорима (Snyder, and Vinjamuri, 2003, str. 13). Надаље, застрашујући учинак правде може се значајно ограничити када је друштво заробљено у перверзни еквилибријум - ситуација у којој појединци нису спремни да обуставе насиље уколико сви не донесу такву одлуку (Katzenstein, and Snyder, 2009, str. 59, 63). Превазилажење тих изазова често налаже давање амнестија, и трговину с главним вођама претходног режима који би у противном били склони да угрозе процес пост-конфликтне институционалне изградње. Јужноафричка Комисија за истину и помирење и амнестије које је Шпанија дала зарад суочавања с фашистичком прошлошћу - овај други случај побуђује интересовање у светлу настојања Шпаније да процесуира Аугуста Пиночеа упркос политичкој одлуци Чилеа да му као сенатору гарантује имунитет (Rodman, 2006, str. 25) - чине новије примере неправног приступа поменутим проблемима политичке транзиције.

Сасвим је могуће сумњати у трансформативне учинке међународних норми. Нарочито у међународној политици, где се легализам сукобљава с политичким захтевима, ка овима другима националне лидере могла би да води разборитост. У међународном окружењу у којем „има много захтева, мноштво норми, асиметрија моћи а ни једна ауторитативна структура доношења одлука”, државе се непотпуно социјализују до усклађивања с међународним нормама и вредностима (Krasner, 1999, str. 9).

\section{Парадокс нелибералног појединца}

Ако се међународно право, како то каже Кан, заиста креће од „учења о државним односима ка режиму индивидуалних права” (Kahn, 2000b, str. 5), онда ће то вероватно водити високо индивидуализованој концепцији личности у којој права - чак и међународна - претходе осталим политичким обавезама. А политичке обавезе се рангирају много шире него права: од породице, заједнице, народног суверена, до институција не-доминације или расуђивања. Иако обавезе не иду - и не треба да иду - тако далеко, и ако су политичке по природи, оне се не могу свести на уску индивидуалну концепцију права без промене нечега фундаменталног у природи либералниог становишта. Ма колико право, процедуре и права либерализму били важни, они су у сваком случају важни унутар институција државе. Ту поменуте обавезе настају као политике институције (било да су делиберативне или институције правде) су места где либералне обавезе стичу своје важење. У сталном одсуству истински ваљаног (то јест, универзалног) институционалног наметања правде, идеја режима индивидуалних права која би заменила доктрину државних односа није само неуверљива, него, изгледа, као да поново уводи неку врсту преполитичке, прсто нелибералне анархије. То, засигурно, не би био полис који би за себе прижељкивали либерални противници државног суверенитета. 


\section{REFERENCES / ЛИTEPATУPA}

Bass, G. J. (2000). Stay the Hand of Justice: The Politics of War Crimes Tribunals. Princeton: Princeton University Press.

Best, G. (1984). Nuremberg and After: The Continuing History of War Crimes and Crimes Against Humanity. University of Reading Press.

Bibas, S. and Burke-White, W. W. (2010). International idealism meets domestic-criminalprocedure realism. Duke Law Journal 59 (4), 637-704.

Brdar, M. and Jokic, A. (2011). Unjust Honoris Causa: Chronicle of a Most Peculiar Academic Dishonor. Kragujevac: Freedom Activities Centre.

Charney, J. I. (1987). Disputes implicating the institutional credibility of the Court: problems of non-appearance, non-participation, and non-performance, in the International Court Of Justice at a crossroads. In L. F. Damrosch (ed.) From International Court of Justice at a Crossroads (pp. 288-319). Ardsley, NY: Transnational Publisher Inc.

Dickson, T. (2015). Shklar's legalism and the liberal paradox. Constellations 22 (2), 188198.

Dossa, S. (1999). Legal liberalism: law, culture and identity. The European Legacy 4, 73-89.

Elshtain, B. J. (2008). Sovereignty: God, State and Self. Basic Books.

Falk, R. (1999). Telford Taylor and the legacy of Nuremberg. Columbia Journal of Transnational Law Association 37, 693-723.

Goldsmith, J. and Krasner, S. (2003). Pitfalls of international idealism. Dedalus 132 (1), 47-63.

Hirsch, F. (2008). The Soviet at Nurmeberg: international law, propaganda, and the making of the postwar order. The American Historical Review 113 (3), 701-730.

Jokic, A. (2004). Genocidalism. The Journal of Ethics 8 (4), 251-97.

Kahn, P. W. (2000a). War powers and the millennium. Loyola of Los Angeles Law Review 34, 11-60.

Kahn, P. W. (2000b). Speaking law to power: Popular Sovereignty, human rights and the new international order. Chicago Journal of International Law 1 (1), 1-18.

Kahn, P. W. (2003) Why the United States is so opposed. Crimes of War Magazine (December 2003); available at http://www.crimesofwar.org/icc_magazine/icc-kahn. html

Kahn, P. W. (2005). Putting Liberalism in its Place. Princeton: Princeton University Press.

Kahn, P. W. (2010). Sacrificial nation. The Utopian, 6 (March 29th 2010); available at http:// www.the-utopian.org/post/2340099709/sacrificial-nation

Kahn, P. W. (2011). Political Theology. New York: Columbia University Press.

Kant, E. (1970). Perpetual Peace. In H. Reiss (ed), Kant's Political Writings (pp. 93-130). Cambridge: Cambridge University Press.

Katzenstein, S. and Snyder, J. (2009). Expediency of the angels. The National Interest (March-April, 2009), pp. 58-65; available at http://nationalinterest.org/print/article/ expediency-of-the-angels-3041

Krasner, S. (1999). Sovereignty: Organized Hypocrisy. Princeton: Princeton University Press.

Maogoto, J. N. (2004). War Crimes and Realpolitik: International Justice from World War I to the $21^{\text {st }}$ Century. Lynne Riener Pub. 
Mégret, F. (2002). The politics of international justice. European Journal of International Law 13 (5), 1261-1284.

Pal, R. (1953). International Military Tribunal for the Far East: Dissentient Judgment of Justice R.B. Pal. Calcutta: Sanyal and Co.

Power, S. (2002). A Problem from Hell: America in the Age of Genocide. New York: Basic Books.

Richardson, H. S. (2002). Democratic Autonomy: Public Reasoning About the Ends of Policy. Oxford University Press.

Rodman, K. (2006). Compromising justice: why the Bush administration and the NGOs are both wrong about the ICC. Ethics \& International Affairs 20 (1), 25-53.

Sellars, K. (2010). Imperfect justice in Nuremberg and Tokyo. European journal of International Law 21 (4), 1085-1102.

Shklar, J. N. (1964). Legalism. Cambridge: Harvard University Press.

Shklar, J. N. (1998). The work of Michael Walzer. In S. Hoffmann (ed.) Political Thought and Political Thinkers (pp. 376-385). Chicago: University of Chicago Press.

Simma, B. (1999). The impact of Nuremberg and Tokyo: attempts at a comparison. In A. Nisuke (ed.) Japan and International Law: Past, Present and Future (pp. 59-84). The Hague: Martinus Nijhoff Publishers.

Snyder, J. and Vinjamuri, L. (2003). Trials and errors: principle and pragmatism in strategies of international justice. International Security 28 (3), 5-44.

Stilz, A. (2009). Liberal Loyalty. Princeton: University Press.

Stone, D. (2002). Policy Paradox: The Art of Political Decision Making. New York: W. W. Norton \& Company.

Walzer, M. (2007). Thinking Politically. Yale University Press.

Превод на српски / Translation into Serbian др Милан Брдар / Milan Brdar PhD 